Article

\title{
Lovastatin Differentially Regulates $\alpha 7$ and $\alpha 4$ Neuronal Nicotinic Acetylcholine Receptor Levels in Rat Hippocampal Neurons
}

\author{
Virginia Borroni ${ }^{1,+} \mathbb{\oplus}$, Constanza Kamerbeek ${ }^{1}$, María F. Pediconi ${ }^{1}$ and Francisco J. Barrantes ${ }^{2, *}$ \\ 1 Instituto de Investigaciones Bioquímicas de Bahía Blanca, Bahía Blanca 8000, Argentina; \\ mvirborroni@gmail.com (V.B.); ckamerbeek@criba.edu.ar (C.K.) \\ 2 Laboratory of Molecular Neurobiology, Institute for Biomedical Research, UCA-CONICET, \\ Faculty of Medical Sciences, Catholic University of Argentina, Av. Alicia Moreau de Justo, \\ Buenos Aires 1600 C1107AAZ, Argentina \\ * Correspondence: francisco_barrantes@uca.edu.ar \\ † Current address: Instituto de Tecnología en Polímeros y Nanotecnología (ITPN-UBA-CONICET), \\ Facultad de Arquitectura, Diseño y Urbanismo, Universidad de Buenos Aires, Ciudad Universitaria, \\ Buenos Aires 1428, Argentina.
}

Academic Editors: Luís M. S. Loura, Maria João Moreno and Anass Jawhari Received: 14 September 2020; Accepted: 18 October 2020; Published: 20 October 2020

\begin{abstract}
Neuronal $\alpha 7$ and $\alpha 4 \beta 2$ are the predominant nicotinic acetylcholine receptor (nAChR) subtypes found in the brain, particularly in the hippocampus. The effects of lovastatin, an inhibitor of cholesterol biosynthesis, on these two nAChRs endogenously expressed in rat hippocampal neuronal cells were evaluated in the $0.01-1 \mu \mathrm{M}$ range. Chronic (14 days) lovastatin treatment augmented cell-surface levels of $\alpha 7$ and $\alpha 4 \mathrm{nAChRs}$, as measured by fluorescence microscopy and radioactive ligand binding assays. This was accompanied in both cases by an increase in total protein receptor levels as determined by Western blots. At low lovastatin concentrations (10-100 nM), the increase in $\alpha 4 \mathrm{nAChR}$ in neurites was higher than in neuronal cell somata; the opposite occurred at higher $(0.5-1 \mu \mathrm{M})$ lovastatin concentrations. In contrast, neurite $\alpha 7 \mathrm{nAChRs}$ raised more than somatic $\alpha 7 \mathrm{nAChRs}$ at all lovastatin concentrations tested. These results indicate that cholesterol levels homeostatically regulate $\alpha 7$ and $\alpha 4 \mathrm{nAChR}$ levels in a differential manner through mechanisms that depend on statin concentration and receptor localization. The neuroprotective pleomorphic effects of statins may act by reestablishing the homeostatic equilibrium.
\end{abstract}

Keywords: nicotinic acetylcholine receptor; cholesterol; hippocampal neurons; upregulation; homeostatic regulation; Alzheimer disease

\section{Introduction}

Nicotinic acetylcholine receptors (nAChR) are prototypic members of the pentameric ligand-gated ion channel (pLGIC) superfamily [1]. Upon binding to the nAChR, acetylcholine-the natural ligand-promotes the opening of this ion channel, formed by five polypeptide subunits organized pseudo-symmetrically around a central pore [2]. In the central nervous system, nAChRs are present as homomeric or heteromeric receptors. The most abundant homomeric nAChR species in the central nervous system is the $\alpha 7 \mathrm{nAChR}$, whereas the majority of the heteromeric nAChRs result from the combination of $\alpha 4$ and $\beta 2$ subunits [3].

The homomeric $\alpha 7$ subtype plays a crucial role in various cognitive functions, including learning and memory $[4,5]$. There is also substantial experimental evidence supporting the notion that $\alpha 7$ nAChRs are critically involved in the pathogenesis of Alzheimer disease (AD) [6-8]. They colocalize with amyloid plaques [9], and the amyloid $\beta$ peptide (A $\beta$ ) binds to $\alpha 7 \mathrm{nAChRs} \mathrm{[9],} \mathrm{probably}$ 
leading to internalization of $A \beta$ by endocytosis with the ensuing build-up of intracellular $A \beta[10,11]$. $\alpha 7 \mathrm{nAChR}$-expressing neurons are the most susceptible to AD neuropathology; both $\alpha 7 \mathrm{nAChR}$ binding sites and $\alpha 7 \mathrm{nAChR}$ protein levels are reduced in the brains of AD patients [6], influencing the neuroinflammation associated with AD [6]. Currently, it is not clear whether downregulation or upregulation of $\alpha 7 \mathrm{nAChRs}$ is related to the pathogenesis of $\mathrm{AD}$. It is likely that interaction of this receptor with $A \beta$ peptides contributes to the pathogenic mechanisms of cholinergic dysfunction [12].

The stability of the nAChR at the cell surface is key to the correct functioning of the cholinergic synapse. Cholesterol in particular is necessary for the maintenance of nAChRs at the plasmalemma and for ion translocation [4]. Previous studies have shown that cholesterol levels modulate the trafficking, membrane domain localization, and function of muscle-type nAChR heterologously expressed in CHO-K1/A5 cells and in endogenously expressed nAChR in C2C12 myotubes [13-19]. Little is known, however, on the effects of cholesterol modulation on neuronal nAChR. In hippocampal slices treated with simvastatin, $\alpha 7 \mathrm{nAChR}$ activity was potentiated without changes in the agonist sensitivity or desensitization kinetics. Enhancement of $\alpha 7 \mathrm{nAChR}$ delivery to the neuronal surface was proposed to be the mechanism behind this phenomenon [20]. In Xenopus laevis oocytes expressing the neuronal $\alpha 7, \alpha 4 \beta 2$, muscle-type, and electric fish electroplaque nAChRs, different degrees of inhibition were obtained by changing the cholesterol/phospholipid ratio in the membrane [21]. Therefore, as with muscle nAChR, it appears that neuronal nAChRs may also be modulated by cholesterol, although further research is required to understand the mechanism of this modulation.

Interestingly, disruption of cholesterol homeostasis has been associated with AD pathogenesis [22-24]. Early epidemiological studies reported a lower risk of dementia in patients under statin treatment $[25,26]$ and, more recently, a combination of statins and antihypertensive drugs was shown to be more effective in reducing the risk of AD and related dementias [22]. Statins reduce cholesterol by inhibiting its biosynthesis at a critical rate-limiting step in the mevalonate pathway, i.e., by blocking the activity of HMG-CoA (5-hydroxy-3-methylglutaryl coenzyme A) reductase in the liver. Moreover, significant levels of statins were detected in mouse brain after chronic oral administration, strongly indicating that statins cross the blood-brain barrier [27]. Statins have pleiotropic effects on brain cells, some of which are not related to inhibition of cholesterol synthesis. These include changes in gene expression, neurotransmitter receptor function, neuronal membrane morphology, neurotransmitter release, and cell viability (see a recent review in [28]). The aim of this study was to characterize the effect of chronic lovastatin treatment on cellular aspects of $\alpha 7$ - and $\alpha 4$-containing nAChRs. We found that lovastatin treatment augments surface expression levels, as well as total expression of $\alpha 7$ and $\alpha 4 \mathrm{nAChRs}$, and that these increases depend on the lovastatin dose and receptor membrane localization.

\section{Results}

\subsection{Chronic Lovastatin Treatment Reduces Cholesterol Levels in Cultured Hippocampal Neurons}

Lovastatin reduces cholesterol levels by inhibiting 3-hydroxy-3-methylglutaryl coenzyme A (HMG-CoA) reductase, the key rate-limiting enzyme in cholesterol biosynthesis. Orally administered lovastatin is able to cross the blood-brain barrier and reach the brain [28]. In primary neuronal cell cultures, the drug has direct accessibility to the target, and the dose-response curves are an accurate representation of the statin concentration in the medium, with sufficient availability and no dilution or barrier effects. In order to assess the effect of chronic lovastatin treatment on the distribution and levels of $\alpha 7$ - and $\alpha 4$-containing nAChRs in neuronal cells, we incubated neurons in primary cultures with different lovastatin concentrations for up to 14 days. Importantly, the expression of nAChRs in hippocampal neurons reaches a stable plateau at day 14-15 in culture [29]. We found that lovastatin treatment significantly reduced total cholesterol levels in cultured neurons in a dose-dependent manner, at all concentrations tested (Figure 1a). We also determined the changes in cell-surface cholesterol levels by measuring the fluorescence intensity of the fluorescein ester of polyethylene glycol-derivatized cholesterol (fPEG-Chol), a cholesterol fluorescent analogue that does not cross 
the plasma membrane. As shown in Figure 1b,c, surface cholesterol levels were reduced in neurons treated with $50 \mathrm{nM}$ lovastatin. This reduction was larger than that observed in total cholesterol levels (Figure 1a). However, the entire neuronal surface was affected similarly by lovastatin treatment. We did not observe differences in surface cholesterol levels between soma and neurites.

a

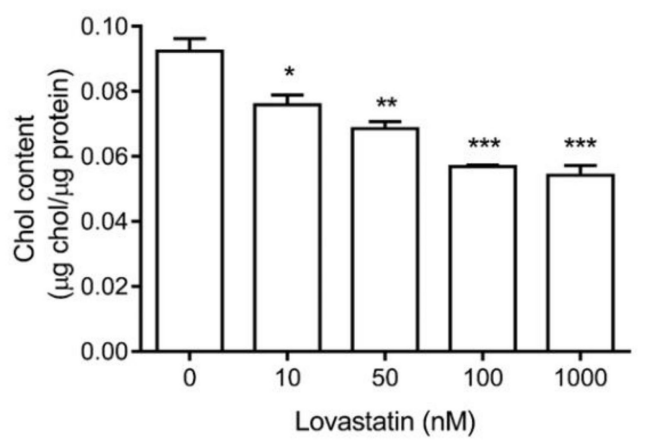

b
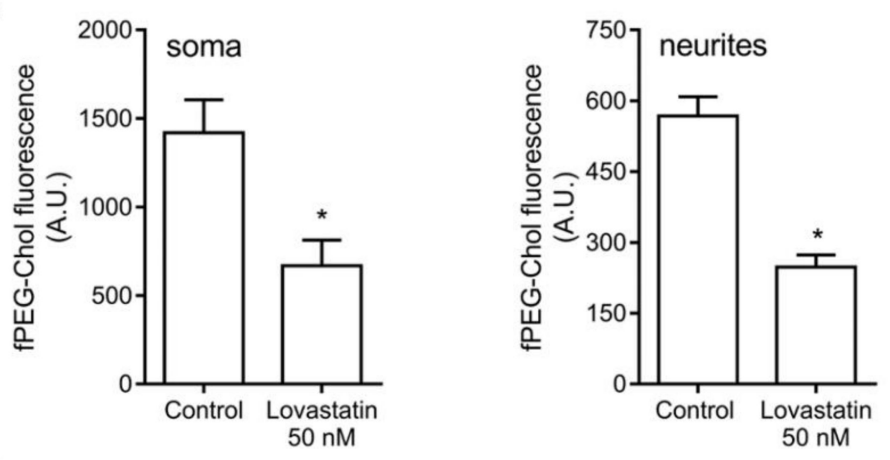

C

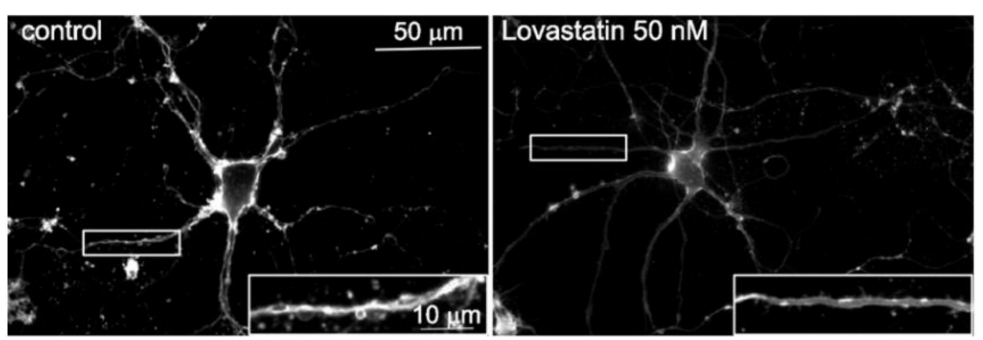

Figure 1. Lovastatin treatment reduced total and surface cholesterol levels in cultured hippocampal neurons. (a) Cultured hippocampal neurons were treated with different lovastatin concentrations for 14 days and, at the end of the incubation, total cholesterol levels were measured. (b) Cultured hippocampal neurons were treated with $50 \mathrm{nM}$ lovastatin for 14 days or left untreated (control). At the end of the incubation, surface cholesterol was identified with the fluorescent analogue fluorescein ester of polyethylene glycol-derivatized cholesterol (fPEG-Chol). Neuronal cells were imaged and fluorescence from the soma and neurites was quantified. (c) Neurons treated as in (b) showing the different regions analyzed. Scale bar: $50 \mu \mathrm{m}$, inset: $10 \mu \mathrm{m}$. Data represent the mean \pm SD of at least three independent experiments. ${ }^{*} p<0.01,{ }^{* *} p<0.0025,{ }^{* * *} p<0.001$.

Importantly, lovastatin applied at a concentration of $1000 \mathrm{nM}$ for 14 days did not reduce neuronal viability (Figure 2). As shown in Figure 2, the wide-field images of treated cultures (c-f) were indistinguishable from untreated control cells $(a, b)$. There were no signs of neuronal damage i.e., loss of integrity of the membrane, shrinkage or vacuolation of the soma, and/or disruption of neurites. Moreover, the percentage of propidium iodide-negative cells in treated and control cultures (control $90 \% \pm 3 \%$ vs. treated with $1000 \mathrm{nM}$ lovastatin $(90 \pm 2 \%, p=0.9955, n=3)$ did not differ at this concentration (Figure $2 \mathrm{~g}$ ). Since the highest concentration tested did not produce any deleterious effects 
on the neuronal cell cultures, it is reasonable to assume that lower concentrations did not compromise neuronal viability either.
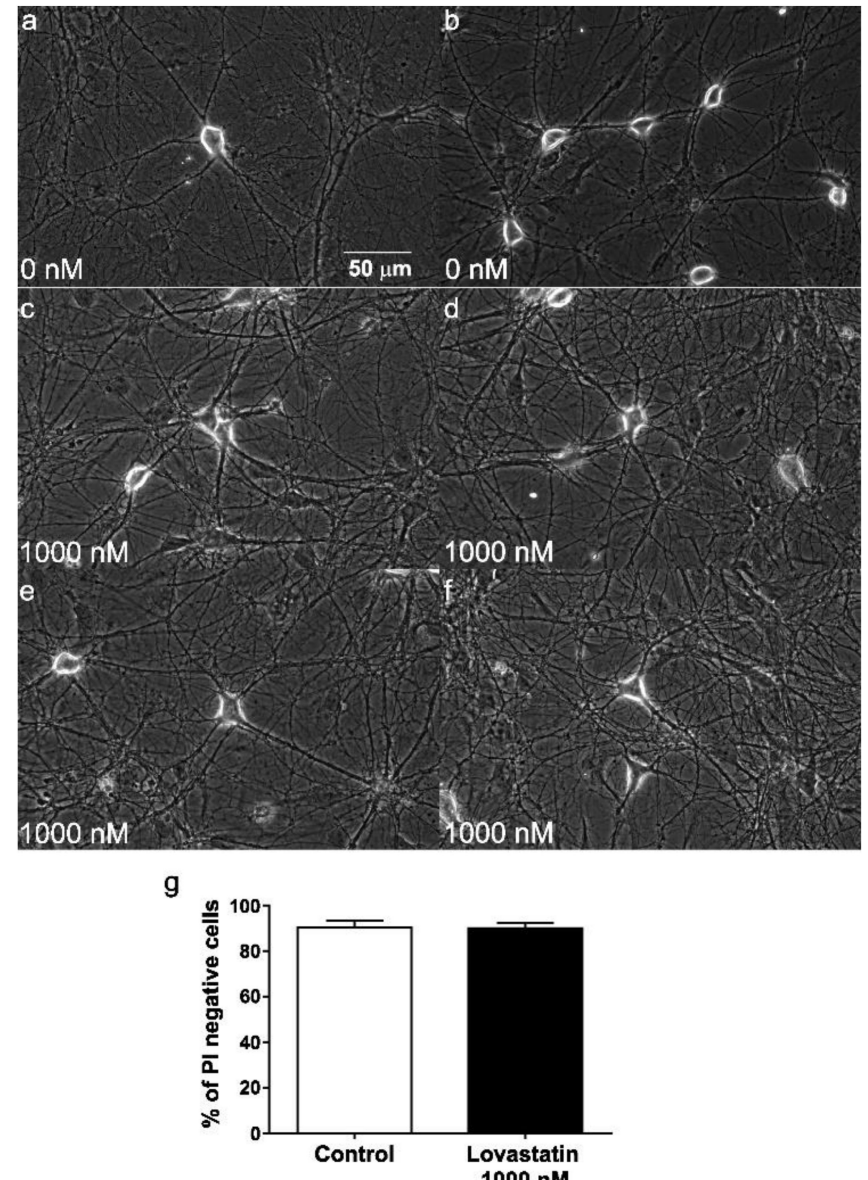

Figure 2. Two independent assays to assess neuronal cell viability of lovastatin treatment. (a) In the example shown, cultured hippocampal neurons were treated $(\mathbf{c}-\mathbf{f})$ with the maximal concentration $(1000 \mathrm{nM})$ of lovastatin or with vehicle in the culture medium $(\mathbf{a}, \mathbf{b})$ for a total of 14 days. Wide-field images of typical cultures. (g) In the parallel fluorescence assay, neurons were stained with the probe propidium iodide (PI) and imaged. The percentage of PI-negative cells was counted and used for comparison with vehicle-treated control cells.

\subsection{Chronic Lovastatin Treatment Increases $\alpha 7 n A C h R$ Levels in Cultured Hippocampal Neurons}

We next evaluated $\alpha 7 \mathrm{nAChR}$ surface levels upon lovastatin treatment by performing binding experiments with the radioactive ligand $\mathrm{I}^{125}-\alpha$-bungarotoxin $(\alpha \mathrm{BTX})$ and fluorescence microscopy experiments with Alexa ${ }^{488}-\alpha B T X$. This toxin is a quasi-irreversible antagonist that binds with high affinity to $\alpha 7 \mathrm{nAChR}$ but not $\alpha 4 \mathrm{nAChR}$, thus providing a specific probe for measuring the $\alpha 7$-type receptor. As shown in Figure 3, the surface area of $\alpha 7 \mathrm{nAChRs}$ in 14 days in vitro neurons was highly variable among experiments (200-2200 fmol/mg protein, $n=17)$. The variability persisted in lovastatin-treated samples, with a statistically significant increase in $\alpha 7 \mathrm{nAChR}$ surface levels. This could be related to the fact that, although pyramidal neurons are the main cell type in the hippocampus, several other types of neuronal cells, particularly interneurons, are also present [30]. The proportion of different neuronal populations may have also varied between different cultures, resulting in the relatively high variability of the data. In fact, the increase became clearly apparent upon normalization of the data (Figure 3b) and was not accompanied by changes in the apparent affinity of $\alpha 7 \mathrm{nAChR}$ for $\alpha \mathrm{BTX}$ (Figure 3c,d), as shown in the Scatchard plots. 
a

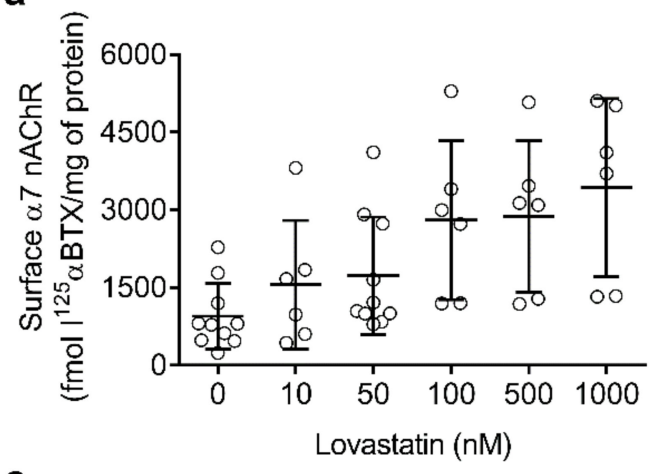

C

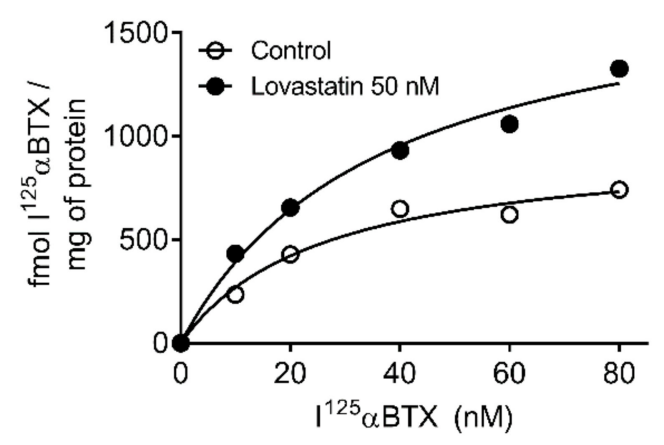

b
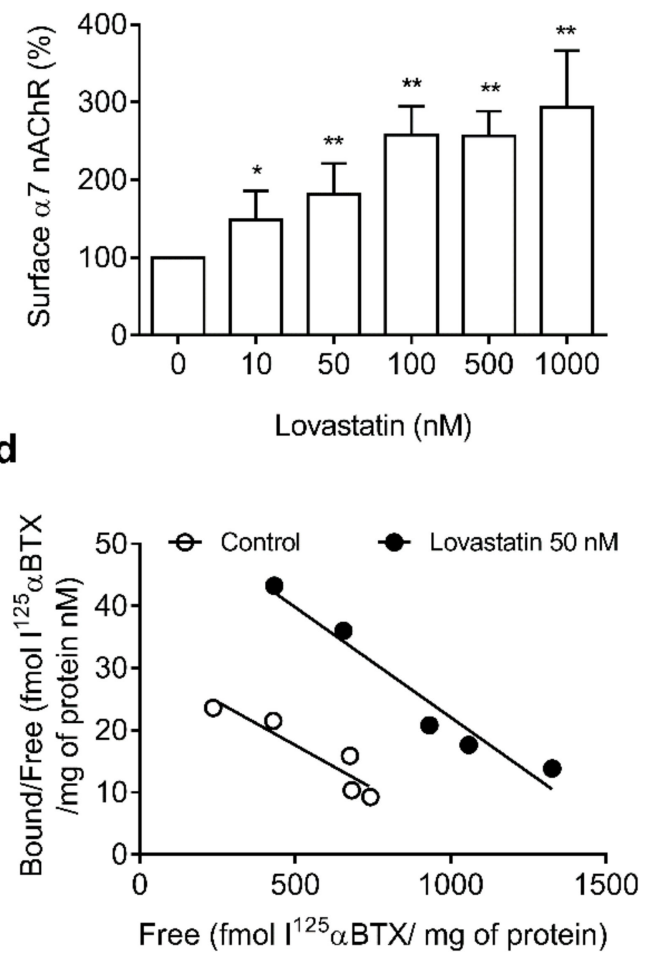

Figure 3. Lovastatin treatment increases surface $\alpha 7$ nicotinic acetylcholine receptor (nAChR) levels in cultured hippocampal neurons. (a) Cultured hippocampal neurons were treated with different lovastatin concentrations for a total of 14 days. At the end of the incubation, neurons were washed, fixed with paraformaldehyde (PF) for $15 \mathrm{~min}$, and labeled with $\mathrm{I}^{125}$ - $\alpha$-bungarotoxin $(\alpha \mathrm{BTX})$. Neurons were washed and specific $\mathrm{I}^{125}-\alpha \mathrm{BTX}$ binding was measured. Data were obtained from at least six experiments $(n=6-17)$ and represented as a scatter plot to show the variability. (b) Normalized data obtained in (a), ${ }^{*} p<0.01 * * p<0.0025$. (c,d) Representative saturation curve and Scatchard plot of data obtained as with $50 \mathrm{nM}$ lovastatin.

2.3. Chronic Lovastatin Treatment Increases Surface $\alpha 7$ and $\alpha 4 n A C h R$ Levels Differentially in Soma and Neurites of Cultured Hippocampal Neurons

Since neurons are highly polarized cells, it was of interest to study whether the changes in $\alpha 7$ $\mathrm{nAChR}$ and $\alpha 4 \mathrm{nAChR}$ levels upon chronic statin treatment differed between soma and neurites (dendrites and axon). To this end, we performed fluorescence microscopy experiments.

Neurons grown for 14 days in vitro in the absence or presence of increasing concentrations of lovastatin were labeled with Alexa ${ }^{488}-\alpha B T X$ and $m A b-299$, a primary monoclonal antibody against the $\alpha 4$ subunit. After labeling with AlexaFluor ${ }^{555}$-labeled secondary antibody, neurons were washed and imaged. Fluorescence associated with AlexaFluor ${ }^{488}-\alpha B T X$ and AlexaFluor ${ }^{555}$-secondary antibody was quantified in the plasma membrane of the neuronal somas and in neurites, as shown in Figure 4. Lovastatin treatment increased surface $\alpha 4$ and $\alpha 7 \mathrm{nAChR}$ levels differentially in soma and neurites. The lovastatin-induced increase in $\alpha 4 \mathrm{nAChR}$ levels was already apparent at lovastatin concentrations as low as $50 \mathrm{nM}$ in both somata and neurites (Figure $4 \mathrm{a}, \mathrm{b}$ ). At higher concentrations of the drug, the increase in neurites was greater than in the soma, reflecting a relative enrichment of $\alpha 4 \mathrm{nAChR}$ in neurite membranes (Figure $4 \mathrm{a}, \mathrm{b}$ ). Lovastatin treatment also increased $\alpha 7 \mathrm{nAChR}$ levels in both soma and neurites, but the increase in neurites was already apparent at lower concentrations $(10 \mathrm{nM})$ than in soma (Figure $4 b, c)$.

The lovastatin-induced increase in $\alpha 4 \mathrm{nAChR}$ levels was already apparent at lovastatin concentrations as low as $50 \mathrm{nM}$ in both somata and neurites (Figure 4a,b). At higher concentrations of 
the drug, the increase in neurites was greater than in the soma, reflecting a relative enrichment of $\alpha 4$ $\mathrm{nAChR}$ in neurite membranes (Figure $4 \mathrm{a}, \mathrm{b}$ ).
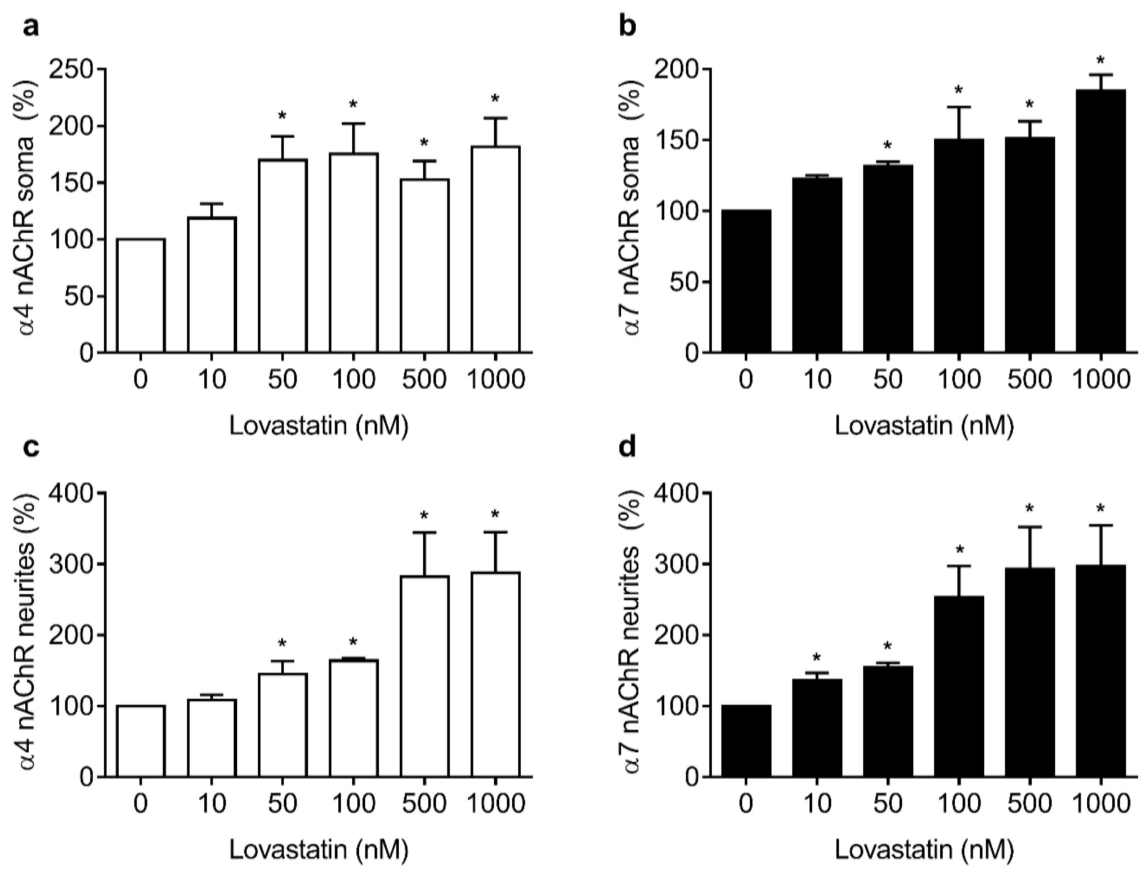

d
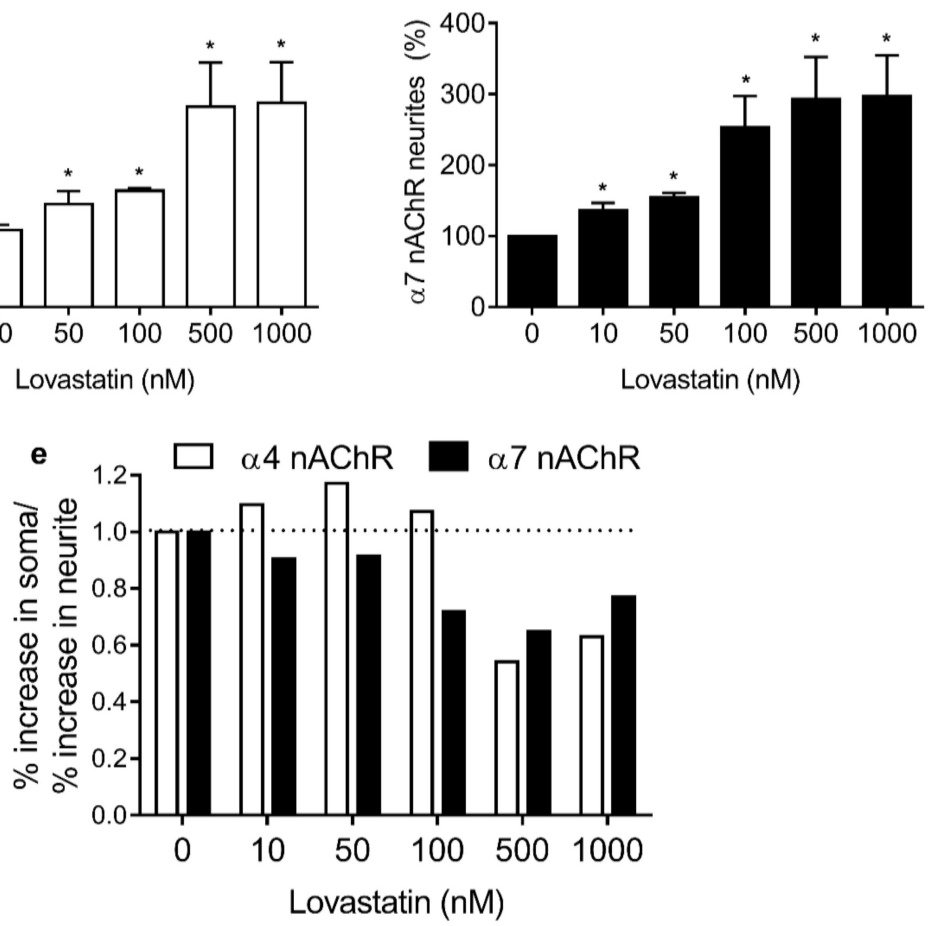

Figure 4. Lovastatin treatment increases surface $\alpha 4$ and $\alpha 7 \mathrm{nAChR}$ levels differentially in soma and neurites. Cultured hippocampal neurons were treated with different lovastatin concentrations for 14 days. At the end of the incubation neurons were washed, fixed with PF for $15 \mathrm{~min}$, and labeled with Alexa Fluor ${ }^{488}$-BTX and mAb-299 (a primary monoclonal antibody against the $\alpha 4$ subunit) and Alexa Fluor ${ }^{555}$ - secondary antibody. Neurons were washed with phosphate-buffered saline (PBS) and imaged by epifluorescence microscopy. Fluorescence corresponding to Alexa Fluor ${ }^{555}(\mathbf{a}, \mathbf{c})$ and Alexa Fluor ${ }^{488}$-BTX (b,d) in soma (upper panel) and neurites (lower panel) was quantified and normalized. Data represent the mean \pm SD from at least three independent experiments. ${ }^{*} p<0.01$. (e) Relative increase in Alexa Fluor ${ }^{555}$ (empty bars) and Alexa Fluor ${ }^{488}$-BTX (black bars) fluorescence in soma and neurites.

Lovastatin treatment also increased $\alpha 7 \mathrm{nAChR}$ levels in both soma and neurites, but the increase in neurites was already apparent at lower concentrations (10 nM) than in soma (Figure $4 b, c)$. When the ratio of the increment percentage in somata and neurites was calculated for each nAChR subtype, differences became more obvious. At low lovastatin concentrations (10-100 nM), the increase in $\alpha 4 \mathrm{nAChR}$ in soma was clearly higher than in neurites (ratio $>1$ ); however, at high lovastatin concentrations, the opposite was apparent (ratio $<1$ ) (Figure $4 \mathrm{~d}$ ). This suggests that the $\alpha 4 \mathrm{nAChR}$ 
present in soma is more sensitive to cholesterol modification than the $\alpha 4 \mathrm{nAChR}$ present in neurites. In contrast, the $\alpha 7 \mathrm{nAChR}$ present in neurites is more sensitive to cholesterol depletion than somatic $\alpha 7 \mathrm{nAChR}$ (Figure $4 \mathrm{~d}$ ).

These differences between somata and neurites could result from differences in the stability of the nAChRs present in each neuronal compartment. To address this possibility, we studied the internalization rate of $\mathrm{nAChR}$ in neuronal somata and neurites upon treatment with $50 \mathrm{nM}$ lovastatin. We chose this concentration because it produces a clear decrease in cholesterol levels well below saturation, which occurs only at higher doses. Neurons were labeled with the anti- $\alpha 4$ monoclonal antibody $\mathrm{mAb}-299$, incubated at $37^{\circ} \mathrm{C}$ for $30 \mathrm{~min}$, and labeled with a secondary antibody at the end of the incubation period. Using this labeling protocol, surface fluorescence was proportional to nAChR levels remaining at the neuronal surface, i.e., not internalized by endocytic mechanisms. As observed previously, lovastatin treatment increased surface $\alpha 4 \mathrm{nAChR}$ levels, and this increment was higher in the neuronal soma. Interestingly, in control neurons, $\alpha 4 \mathrm{nAChRs}$ were internalized in the soma at a faster rate than in the neurites $(75.2 \% \pm 15.9 \% \alpha 4 \mathrm{nAChR} / 30 \mathrm{~min}$ vs. $101.2 \% \pm 2.7 \% \alpha 4 \mathrm{nAChR} / 30 \mathrm{~min}$, $p \leq 0.001$, Figure $5 \mathrm{~b}, \mathrm{~d}, 30 \mathrm{~min}$ control). Moreover, the internalization rate of $\alpha 4 \mathrm{nAChR}$ in soma was not affected by lovastatin treatment $(75.2 \% \pm 15.9 \% \alpha 4 \mathrm{nAChR} / 30 \mathrm{~min}$ vs. $77.9 \% \pm 19.0 \% \alpha 4 \mathrm{nAChR} / 30 \mathrm{~min}$ $p=0.791$, Figure $5 \mathrm{~b}, 30 \mathrm{~min}$ control vs. lovastatin), whereas, in neurites, $\alpha 4 \mathrm{nAChR}$ internalization was accelerated upon cholesterol depletion $(101.2 \% \pm 2.7 \% \alpha 4 \mathrm{nAChR} / 30 \mathrm{~min}$ vs. $51.1 \% \pm 3.9 \% \alpha 4$ $\mathrm{nAChR} / 30 \mathrm{~min}, p \leq 0.001$, Figure $5 \mathrm{~d}, 30 \mathrm{~min}$ control vs. lovastatin). However, the internalization rate of $\alpha 7 \mathrm{nAChR}$ present in the soma was not affected by cholesterol depletion $(58.8 \% \pm 20.2 \% \alpha 7$ $\mathrm{nAChR} / 30 \mathrm{~min}$ vs. $74.2 \% \pm 18.2 \% \alpha 7 \mathrm{nAChR} / 30 \mathrm{~min}, p=0.228$, Figure $6 \mathrm{~b}, 30 \mathrm{~min}$ control vs. lovastatin), whereas $\alpha 7 \mathrm{nAChR}$ internalization was accelerated in neurites $(63.2 \% \pm 6.9 \% \alpha 7 \mathrm{nAChR} / 30 \mathrm{~min}$ vs. $90.3 \% \pm 8.4 \% \alpha 7 \mathrm{nAChR} / 30 \mathrm{~min}, p \leq 0.001$, Figure $6 \mathrm{~d}, 30 \mathrm{~min}$ control vs. lovastatin).
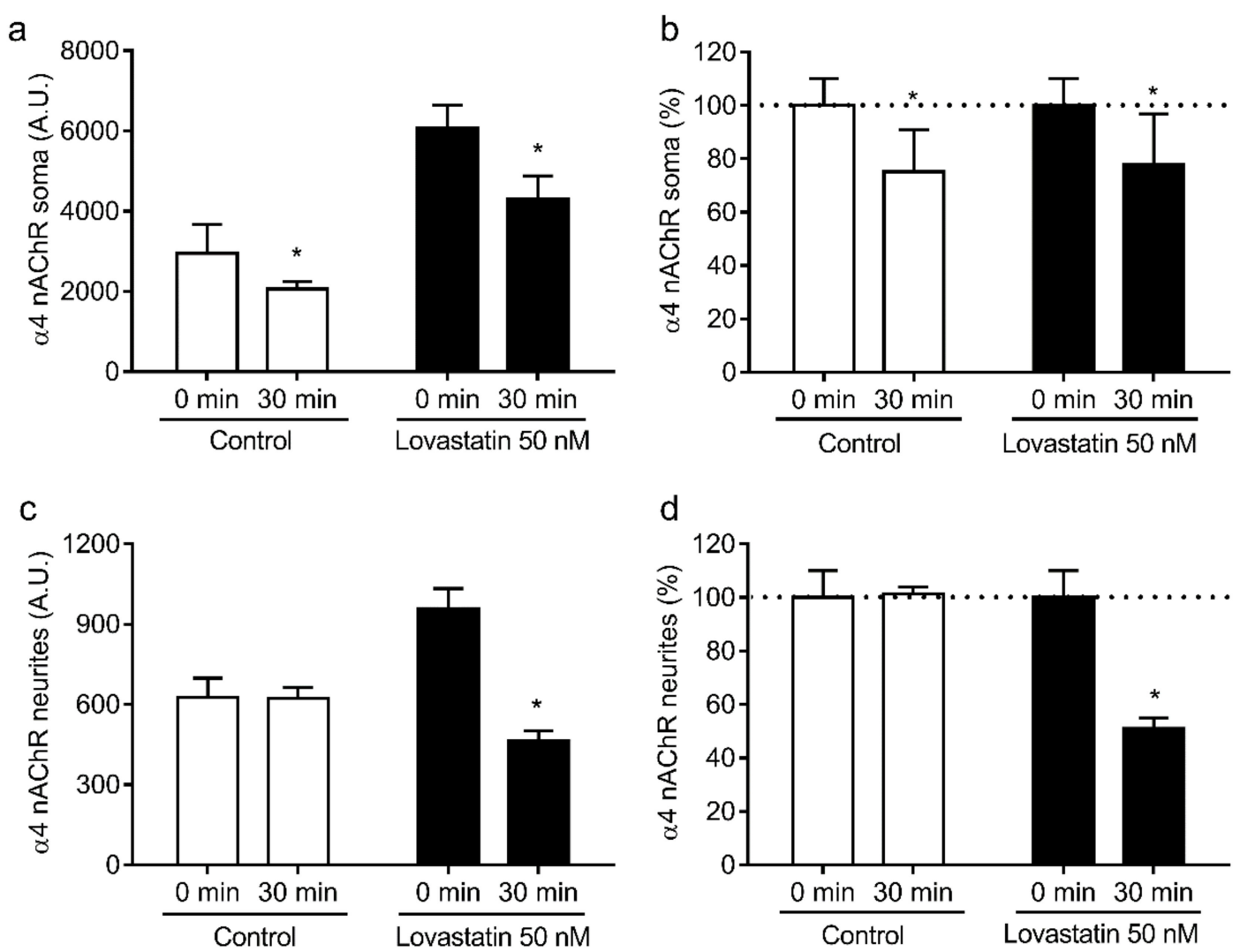

Figure 5. Lovastatin treatment affects surface $\alpha 4 \mathrm{nAChR}$ internalization differentially in soma and neurites. Cultured hippocampal neurons were treated with $50 \mathrm{nM}$ lovastatin for 14 days or left untreated 
(control). At the end of the incubation, neurons were washed, labeled with $\mathrm{mAb}-299$ for $1 \mathrm{~h}$ at $4{ }^{\circ} \mathrm{C}$, and then transferred to an incubation bath at $37^{\circ} \mathrm{C}$ for $30 \mathrm{~min}$. After the incubation, neurons were fixed and $\alpha 4 \mathrm{nAChRs}$ remaining at the surface were revealed by labeling with Alexa Fluor ${ }^{555}$-secondary antibody. Fluorescence was quantified by fluorescence microscopy in soma $(\mathbf{a}, \mathbf{b})$ and neurites $(\mathbf{c}, \mathbf{d})$ and expressed in arbitrary units (AU) or normalized against the fluorescence obtained without incubation at $37^{\circ} \mathrm{C}(0 \mathrm{~min})$. Data represent the mean $\pm \mathrm{SD}$ from at least three independent experiments. ${ }^{*} p<0.01$.

a

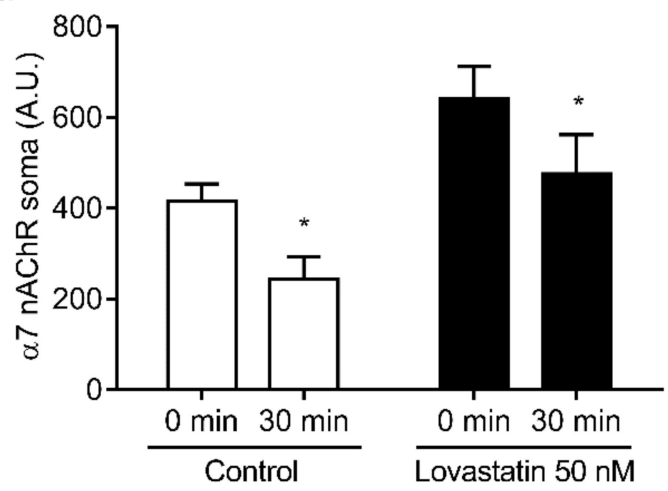

C

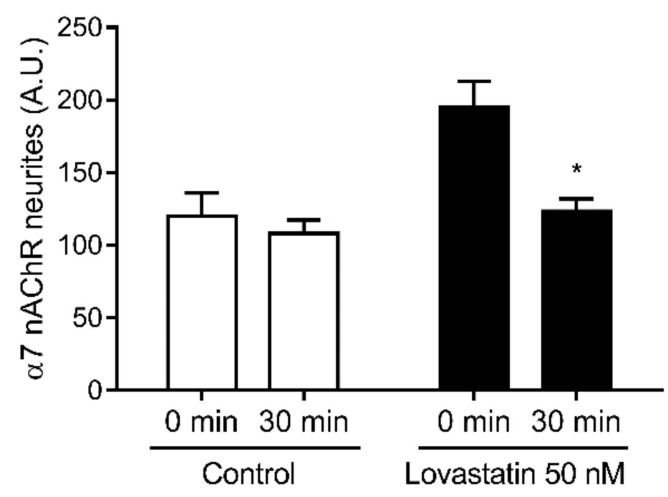

b

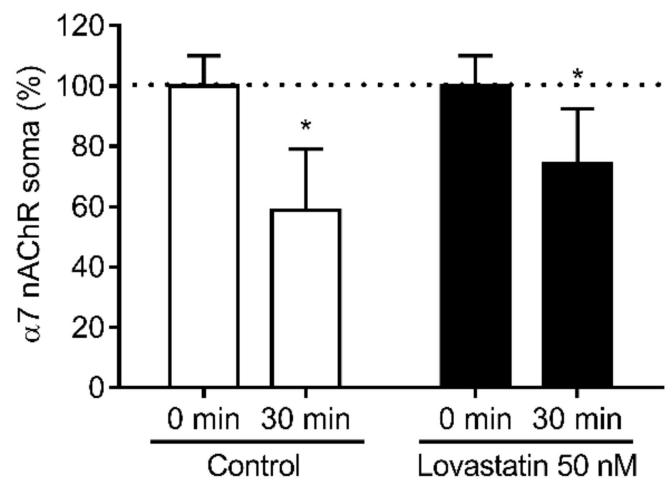

d

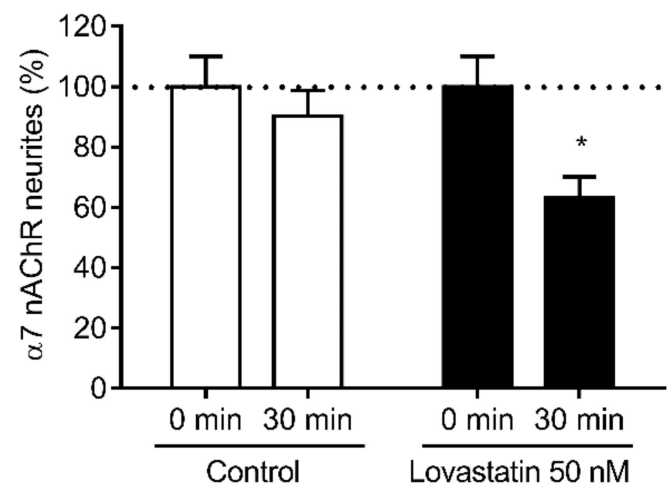

Figure 6. Lovastatin treatment affects surface $\alpha 7 \mathrm{nAChR}$ internalization differentially in soma and neurites. Cultured hippocampal neurons were treated with $50 \mathrm{nM}$ lovastatin for a total of 14 days or left untreated (control). At the end of the incubation, neurons were washed, labeled with biotin-BTX for $1 \mathrm{~h}$ at $4{ }^{\circ} \mathrm{C}$, and then transferred to an incubation bath at $37^{\circ} \mathrm{C}$ for $30 \mathrm{~min}$. After the incubation, neurons were fixed, and $\alpha 7 \mathrm{nAChRs}$ remaining at the surface were revealed by labeling with Alexa ${ }^{488}$-streptavidin. Fluorescence was quantified by fluorescence microscopy in soma $(\mathbf{a}, \mathbf{b})$ and neurites $(\mathbf{c}, \mathbf{d})$ and expressed in arbitrary units (AU) or normalized against the fluorescence obtained without incubation at $37^{\circ} \mathrm{C}$ $(0 \mathrm{~min})$. Data represent the mean \pm SD from at least three independent experiments. ${ }^{*} p<0.01$.

\subsection{Chronic Lovastatin Treatment Increases $\alpha 4$ and $\alpha 7 n A C h R$ Total Levels in Cultured Hippocampal Neurons}

The increase in cell-surface $\alpha 4$ and $\alpha 7 \mathrm{nAChRs}$ could also result from an increase in receptor synthesis and membrane insertion. To test this hypothesis, we measured total (internal + surface) $\alpha 7$ and $\alpha 4 \mathrm{nAChR}$ levels in permeabilized neurons treated with $50 \mathrm{nM}$ lovastatin using two independent assays: fluorescence microscopy and Western blotting. The two methods employed concurrently demonstrated that lovastatin treatment increased total $\alpha 7$ and $\alpha 4 \mathrm{nAChR}$ levels with respect to control, untreated neurons (Figure 7). 
$\alpha 4$ AChR

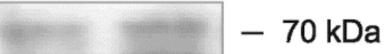

actin
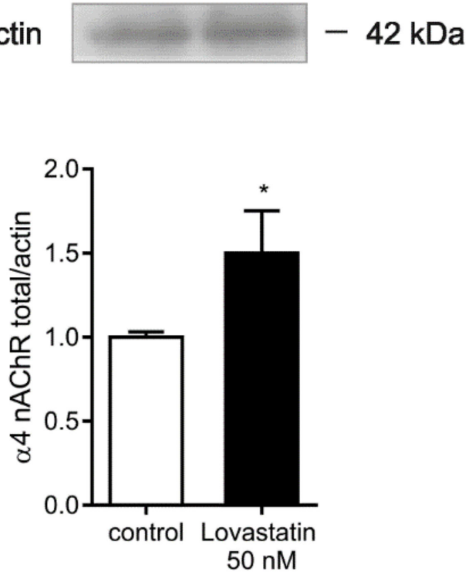

b

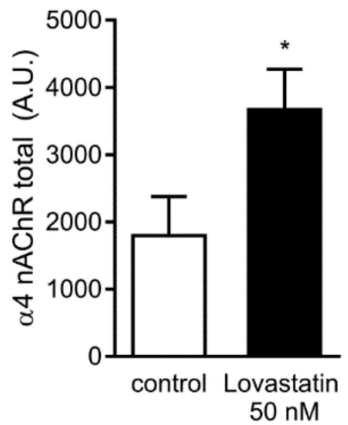

$\alpha 7 \mathrm{AChR}=-56 \mathrm{kDa}$

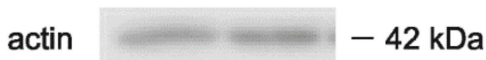

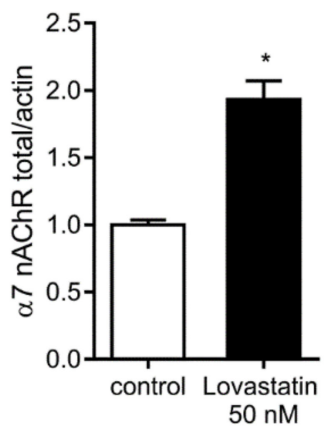

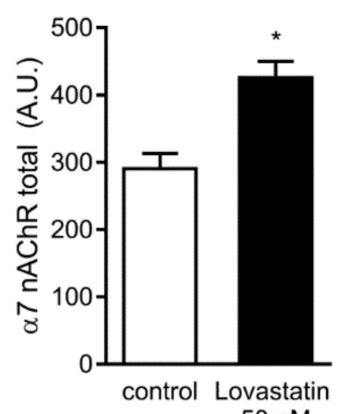

Figure 7. Lovastatin treatment increased total $\alpha 7$ and $\alpha 4$ nAChR levels. (a) $\alpha 7$ and $\alpha 4$ nAChR subunits revealed in immunoblots of cultured hippocampal neurons treated with $50 \mathrm{nM}$ lovastatin for 14 days or left untreated (control). Actin was used as loading control. Lower panel: quantification of $\alpha 7$ and $\alpha 4 \mathrm{nAChR}$ subunits against actin. Data represent the mean \pm SD from at least three independent experiments. (b) Cultured hippocampal neurons were treated with $50 \mathrm{nM}$ lovastatin for 14 days or left untreated (control). At the end of the incubation, neurons were fixed, permeabilized, and labeled with Alexa Fluor ${ }^{488}$-BTX and mAb-299 for $1 \mathrm{~h}$ at room temperature. After washing, neurons were incubated with Alexa Fluor555-secondary antibody for 2 h, washed with PBS, and imaged; then, fluorescence was quantified. Data represent the mean \pm SD from at least three independent experiments. ${ }^{*} p<0.01$.

\section{Discussion}

Although the brain accounts for only $2 \%$ of the total weight of our organism, its cholesterol content amounts to $\sim 25 \%$ of the total [31]. Another peculiarity of brain cholesterol is that its content is regulated autonomously due to the impermeability of the blood-brain barrier to macromolecules involved in cholesterol transport, such as the plasma lipoproteins [30]. Here, we found that chronic lovastatin treatment reduced total cholesterol levels in neuronal cells, even at low doses. More relevant, the neuronal membrane was evenly depleted in cholesterol. Interestingly, the results obtained with neuronal cells in culture correlate well with those from in vivo studies. Chronic administration of hydrophobic statins such as lovastatin or simvastatin and the more hydrophilic statin, pravastatin, specifically reduces neuronal membrane cholesterol levels in vivo, as measured in synaptosomal membranes and brain membranes of mice. In particular, lovastatin and pravastatin were shown to 
significantly reduce the cholesterol content of cholesterol-rich microdomains in the exofacial leaflet of the membrane [32,33]. However, it is worth mentioning that these drugs have effects on cells beyond inhibition of cholesterol biosynthesis [28].

Cholesterol exerts effects on multiple aspects of synaptic transmission [34], both presynaptically, acting on neurotransmitter vesicle fusion [35], and postsynaptically, modifying neurotransmitter receptor diffusion and domain localization in the postsynaptic membrane [36], endosomal dynamics [37], and receptor ion translocation [38]. Therefore, it is unlikely that the nAChR constitutes the only target of lovastatin treatment.

Life-long synaptic activity and accumulated metabolic stress appear to contribute to a moderate but irreversible loss of membrane cholesterol in the aging brain $[39,40]$. It has been speculated that this loss underlies neuronal dysfunctions and the cognitive deficits present at this stage of life [41-43]. It has also been surmised that dysregulation of cholesterol metabolism is a major factor in neurological diseases accompanied by cognitive dysfunction, such as Alzheimer disease [44,45] (reviewed in [23]), Parkinson disease [46], and Huntington disease [47]. Epidemiological studies have suggested that individuals treated with statins have a lower risk of developing Alzheimer disease [25,28,48]. In this study, we demonstrated that chronic statin treatment increased both $\alpha 7$ and $\alpha 4 \mathrm{nAChR}$. At low lovastatin doses, there was an enrichment of $\alpha 4 \mathrm{nAChR}$ in neuronal somata, whereas, at high doses, the increase in $\alpha 4$ in neurites was more prominent. Interestingly, $\alpha 7 \mathrm{nAChRs}$ in neurites (axon + dendrites) were more susceptible to lovastatin treatment. At all doses tested, the increase in neurite $\alpha 7$ was higher than in somatic $\alpha 7$. Neurites are the site where most of the synaptic transmission occurs. Thus, changes in the relative amount of neurotransmitter receptors, as shown in this work, may have profound effects on synaptic responses. Indeed, hippocampal slices treated with simvastatin showed a significant potentiation of $\alpha 7 \mathrm{nAChR}$ activity without changes in agonist sensitivity or in the kinetics of desensitization [20]. Our results suggest that the mechanism behind this phenomenon is an increase in $\alpha 7 \mathrm{nAChR}$ delivery to the neuronal surface. Given the marked cholinergic deficit in AD [12,49], the neuroprotective effect mediated by chronic statin treatment could be related to the increase in surface $\mathrm{nAChR}$ and the consequent maintenance/restoration of cholinergic activity.

The mechanism via which lovastatin treatment increases nAChR levels may involve multiple stages. The internalization rate of neuronal $\mathrm{nAChRs}$ varies according to receptor type and localization. Whereas the internalization rate of $\alpha 4$ in neuronal cell somata was not affected at $50 \mathrm{nM}$ lovastatin, it increased in neurites, and this phenomenon may explain the relative increase of $\alpha 4 \mathrm{nAChR}$ in somata at this lovastatin concentration. The $\alpha 7 \mathrm{nAChR}$ internalization rate in neuronal somata was slightly hindered at $50 \mathrm{nM}$ lovastatin, whereas, in neurites, it was markedly augmented. Interestingly, the global result was a net increase in neurite $\alpha 7 \mathrm{nAChR}$. Preferential neurite insertion of newly synthesized receptors may explain the differences. Moreover, total nAChR levels were increased, and this may also contribute to the gain in surface $n A C h R$ receptor pool. This is in agreement with the results of Roentsch and coworkers [50], who demonstrated that a series of statins, including lovastatin, augmented the expression of $\alpha 7$ subunit messenger RNA (mRNA) in SH-SY5Y cells. Similar results were obtained in hippocampal slices by Chen et al. [51], although, in this case, no increase in $\alpha 4$ mRNA expression was observed. It is important to note that protein expression was not measured in the latter study. An increase in $\alpha 4 \mathrm{nAChR}$ protein stability may explain the increase observed here. nAChRs are very sensitive to membrane cholesterol levels; ion translocation properties, membrane domain localization, rate and mechanism of internalization, and exocytic trafficking are strongly dependent on membrane cholesterol in muscle nAChR [13-16,19]. The results presented in this paper indicate that the cholesterol dependence may be a hallmark not only of the muscle-type nAChR but of the entire nAChR family.

In addition to lowering cholesterol levels, statins also have pleiotropic effects, including immunomodulatory [52], antioxidant, and anti-inflammatory [28,53,54] effects that may be related to their purported beneficial effects on Alzheimer disease. The homeostatic modulation of $\alpha 7$ and $\alpha 4$ 
nAChRs levels by cholesterol could be a hitherto ignored mechanism via which statins exert their neuroprotective action.

\section{Materials and Methods}

\subsection{Materials}

2-Methyl-1,2,3,7,8,8a-hexahydro-3,7-dimethyl-8-[2-(tetrahydro-4-hydroxy-6-oxo-2H-pyran-2yl)ethyl]-1-naphthalenyl ester butanoic acid), "lovastatin", $\alpha$-bungarotoxin $(\alpha B T X)$, bovine serum albumin (fraction $\mathrm{V}$, cell culture tested), ovalbumin, chloramine $\mathrm{T}$, sodium metabisulfite, rat anti-nAChR $\alpha 4$ subunit monoclonal antibody $\mathrm{mAb}-299$, glutamine, propidium iodide, sodium pyruvate, and poly-L-lysine hydrobromide were purchased from Sigma Chemical Company (St. Louis, MO, USA). [ ${ }^{125}$ I]iodine was obtained from Perkin Elmer (Wellesley, MA, USA). Alexa Fluor ${ }^{488}$-conjugated $\alpha$ BTX (Alexa Fluor $^{488}-\alpha B T X$ ), biotin- $\alpha$ BTX, and Alexa Fluor ${ }^{633}$-streptavidin were purchased from Molecular Probes (Eugene, OR, USA). Neurobasal, trypsin, cytosine arabinoside, N2, and B27 supplements were from Invitrogen (Carlsbad, CA, USA). Rabbit ab-23832 anti- $\alpha 7 \mathrm{nAChR}$ polyclonal antibody and anti-actin were purchased from AbCam (Eugene, OR, USA). Mouse monoclonal antibody anti-tubulin was purchased from BD Biosciences (San Jose, CA, USA). Horseradish peroxidase (HRP)-conjugated goat anti-rabbit and goat anti-mouse secondary antibodies were purchased from Santa Cruz Biotechnology, Inc. (Santa Cruz, CA, USA). The fluorescein ester of polyethylene glycol-derivatized cholesterol (fPEG-Chol) was a gift from Prof. T. Kobayashi and Dr. Satoshi B. Sato, and anti- $\alpha 7 \mathrm{nAChR}$ monoclonal antibodies mAb-306 and mAb-307 were gifts from Dr. Jon Lindstrom, University of Pennsylvania.

\subsection{Hippocampal Cultures}

Dissociated neuronal cultures were prepared from hippocampi of embryonic day 19, as previously described [55]. Briefly, brain tissue was treated with $0.25 \%$ trypsin in Hanks' solution at $37^{\circ} \mathrm{C}$ for $15 \mathrm{~min}$. A single-cell solution was prepared in Neurobasal (NB) medium containing $2 \mathrm{mM}$ glutamine, $10 \mu \mathrm{M}$ sodium pyruvate, $100 \mathrm{units} / \mathrm{mL}$ penicillin, and $100 \mu \mathrm{g} / \mathrm{mL}$ streptomycin (NB1X) with $10 \%(v / v)$ horse serum. Cells were seeded on coverslips coated with $0.1 \mathrm{mg} / \mathrm{mL}$ poly-L-lysine hydrobromide at a density of 30,000 cells $/ \mathrm{cm}^{2}$. After $2 \mathrm{~h}$, the medium was changed to NB/N2 (NB1X with $1 \mathrm{~g} / \mathrm{L}$ ovalbumin; N2 and B27 serum-free supplements). On day 3, cytosine arabinoside was added to inhibit glial development. On the basis of morphological characteristics, it was estimated that $>90 \%$ of the cells in the primary culture were neurons. Lovastatin treatment started at 6 days in vitro.

\subsection{Protein Content}

Protein content was determined using the method of Lowry et al. (1951) upon solubilization of cells with $0.1 \mathrm{~N} \mathrm{NaOH}$, using bovine serum albumin (BSA) as a standard.

\subsection{Cholesterol Determination}

Total cholesterol content was measured using a commercial kit (Colestat, AA, Wiener, Rosario, Argentina) following manufacturer's instructions.

Surface cholesterol was evaluated by incubation of the neurons with $1 \mu \mathrm{M}$ fPEG-Chol in phosphate-buffered saline (PBS) at $4{ }^{\circ} \mathrm{C}$, followed by washing with PBS and observation under the microscope.

\section{5. $\alpha$ BTX Radioiodination}

For all binding experiments, the specific ligand $\left[{ }^{125} \mathrm{I}\right]-\alpha$-bungarotoxin $\left(\left[{ }^{125} \mathrm{I}\right]-\alpha \mathrm{BTX}\right)$ was prepared in our laboratory. To this end, $80 \mu \mathrm{g}$ of $\alpha \mathrm{BTX}$ was mixed with $2 \mu \mathrm{L}$ of chloramine $\mathrm{T}(40 \mathrm{mg} / \mathrm{mL})$ and with $0.66 \mathrm{mCi}\left[{ }^{125} \mathrm{I}\right] \mathrm{Na}$ for $2 \mathrm{~min}$ at room temperature. The reaction was stopped by addition of $2 \mu \mathrm{L}$ of sodium metabisulfite solution at a final concentration of $40 \mathrm{mg} / \mathrm{mL}$. The mixture was subsequently applied to a G25 medium Sephadex (Pharmacia) column where the resulting iodinated $\left[{ }^{125} \mathrm{I}\right]-\alpha \mathrm{BTX}$ 
was separated from the free iodine. The specific activity of the $\left[{ }^{125} \mathrm{I}\right]-\alpha \mathrm{BTX}$ obtained amounted to $\sim 50 \mu \mathrm{Ci} / \mathrm{mmol}$.

\subsection{Equilibrium $\left[{ }^{125} I\right]-\alpha B T X$ Binding Studies}

Surface nAChR expression was determined by incubating 70-80\% confluent neuronal cells with increasing concentrations $(10-60 \mathrm{nM})$ of $\left[{ }^{125} \mathrm{I}\right]-\alpha \mathrm{BTX}$ in the cell culture medium at $25^{\circ} \mathrm{C}$ for $50 \mathrm{~min}$. After incubation, dishes were washed twice with phosphate buffer, and cells were removed and collected by addition of $1.5 \mathrm{~mL}$ of $0.1 \mathrm{~N} \mathrm{NaOH}$. Radioactivity was measured in a gamma counter with $80 \%$ efficiency. Nonspecific binding was determined from the radioactivity remaining in the dishes after preincubation of cells with $50 \mathrm{mM}$ carbamoylcholine chloride for $1 \mathrm{~h}$ before addition of $\left[{ }^{125} \mathrm{I}\right]-\alpha \mathrm{BTX}$. Non-specific binding amounted to $<10 \%$ in all experiments. Determination of the total pool of $\mathrm{nAChR}$ was carried out upon permeabilization of cells with $0.5 \%$ saponin. The nAChR intracellular pool was calculated as the difference between the total and $\left[{ }^{125} \mathrm{I}\right]-\alpha \mathrm{BTX}$ surface binding sites.

\subsection{Cell-Surface $\alpha 7$ and $\alpha 4 n A C h R$ Labeling}

Neurons were fixed with $2 \%$ paraformaldehyde for $15 \mathrm{~min}$ and subsequently incubated overnight with $\mathrm{mAb}-299$ in PBS/BSA at $4{ }^{\circ} \mathrm{C}$. At the end of the incubation neurons, were washed thrice with PBS and incubated with Alexa Fluor ${ }^{488}-\alpha B T X$ or Alexa Fluor ${ }^{555}$-secondary antibody for $2 \mathrm{~h}$ at room temperature.

\subsection{Internalization Assay}

Neurons were incubated with mAb-299 or biotin- $\alpha$ BTX in Neurobasal medium for $1 \mathrm{~h}$ at $4{ }^{\circ} \mathrm{C}$, and then transferred to a thermostatic bath at $37^{\circ} \mathrm{C}$ for an additional $30 \mathrm{~min}$ period. At the end of the incubation, neurons were fixed for $15 \mathrm{~min}$ in $2 \%$ paraformaldehyde, washed thrice with PBS, and labeled with Alexa ${ }^{488}$-streptavidin or Alexa Fluor ${ }^{555}$-secondary antibody for $2 \mathrm{~h}$ at room temperature.

\subsection{Fluorescence Microscopy}

Labeled neurons were examined with a Nikon Eclipse E-600 microscope. Imaging was accomplished with a SBIG model ST-7 digital charge-coupled device camera $(765 \times 510$ pixels, $9.0 \times 9.0 \mu \mathrm{m}$ pixel size; Santa Barbara, CA, USA). The ST-7 CCD camera was driven by the CCDOPS software package (SBIG Astronomical Instruments, version 5.02). For all experiments, 40× (1.3 numerical aperture (NA)) or $100 \times(1.4 \mathrm{NA})$ oil-immersion objectives were used. Appropriate dichroic and emission filters were used to avoid crossover of fluorescence emission. Then, 8 bit or 16 bit TIFF images were exported for further off-line analysis.

\subsection{Quantitative Image Analysis}

Fluorescence intensities of the 8 or 16 bit images were analyzed after manually outlining regions of interest (ROI) with the software Image J (NIH, Bethesda, MD, USA). The average fluorescence intensity of a given ROI was measured, and the average fluorescence intensity of an area of the same field outside the neuron was subtracted. These measurements were undertaken on randomly chosen neurons, selected from phase-contrast images to avoid bias, for each experimental condition. For illustration purposes, images were scaled with identical parameters, and pseudo-colored according to a custom designed look-up-table (LUT).

\subsection{Western Blotting}

At the end of each treatment, neurons were harvested and lysed at $4{ }^{\circ} \mathrm{C}$ for $1 \mathrm{~h}$ with cell lysis buffer (20 mM 4-(2-hydroxyethyl)-1-piperazineethanesulfonic acid (HEPES); $10 \mathrm{mM}$ ethylene glycol tetraacetic acid (EGTA); $5 \mathrm{mM} \beta$-glicerophosphate, $1 \%$ Nonidet P-40; $2.5 \mathrm{mM} \mathrm{MgCl}_{2}$ ) containing protease inhibitors ( $1 \mathrm{mM}$ dithiothreitol (DTT); $2 \mu \mathrm{g} / \mathrm{mL}$ leupeptin; $1 \mu \mathrm{g} / \mathrm{mL}$ aprotinin; $1 \mu \mathrm{g} / \mathrm{mL}$ pepstatin; $0.1 \mathrm{mM}$ phenylmethylsulfonyl fluoride (PMSF)). The neuron suspension was centrifuged at 13,200 rpm for $20 \mathrm{~min}$ 
at $4{ }^{\circ} \mathrm{C}$. The supernatant was subsequently collected, and protein content was determined following the procedure of Lowry et al. (1951). Samples were then denatured with Laemmli buffer at $100{ }^{\circ} \mathrm{C}$ for $5 \mathrm{~min}$ and proteins were resolved by sodium dodecyl sulfate polyacrylamide gel electrophoresis (SDS-PAGE) on 10\% polyacrylamide gels and subsequently transferred to polyvinylidene fluoride (PVDF) membranes (Millipore, Bedford, MA, USA). These membranes were blocked with 10\% BSA in Tris-buffered saline/Tween-20 (TBST) buffer (20 mM Tris- $\mathrm{HCl}$ (pH 7.4) containing $100 \mathrm{mM} \mathrm{NaCl}$ and $0.1 \%(w / v)$ Tween-20) at room temperature for $2 \mathrm{~h}$. Membranes were subsequently incubated overnight at $4{ }^{\circ} \mathrm{C}$ with a 1:1000 dilution of primary antibodies (anti- $\alpha 7 \mathrm{nAChR}$, anti- $\alpha 4 \mathrm{nAChR}$, and anti-actin), washed thrice with TBST, and subsequently exposed to the appropriate HRP-conjugated secondary antibody (anti-rabbit or anti-mouse) for $2 \mathrm{~h}$ at room temperature. Membranes were washed again three times with TBST and immunoreactive bands were detected upon exposure to the enhanced chemiluminescence reagent (ECL, Amersham Biosciences) using standard X-ray film (Kodak X-Omat AR). About $40-50 \mu \mathrm{g}$ of proteins were loaded per lane in all experiments.

\subsection{Viability Assays}

The number of dead neurons was quantified by propidium iodide (PI) staining. Briefly, PI ( $2 \mu \mathrm{M})$ was added to control and lovastatin-treated neurons, and the culture plates were incubated for $30 \mathrm{~min}$ at $37^{\circ} \mathrm{C}$. The medium was then removed and the neurons were washed three times with PBS, followed by observation under an inverted fluorescence microscope with appropriate filters (excitation maximum, $535 \mathrm{~nm}$; emission maximum, $617 \mathrm{~nm}$ ) to estimate the number of PI-positive cells.

\subsection{Data Analysis}

Data were analyzed using GraphPad Prism program from GraphPad Software Inc., San Diego, CA, USA. Statistically significant differences were determined by Student's $t$-test (two-tailed) or one-way ANOVA with Tukey post hoc test, as appropriate.

Author Contributions: Conceptualization, V.B. and F.J.B.; methodology, M.F.P., V.B., and C.K.; writing-review and editing, V.B. and F.J.B.; funding acquisition, F.J.B. and M.F.P. All authors have read and agreed to the published version of the manuscript.

Funding: This work was supported by grants PIP No. N ${ }^{\circ}$ 5205/15 from the National Scientific and Technical Research Council of Argentina (CONICET) and PICT No. 2015-2654 from the Ministry of Science, Technology and Productive Innovation of Argentina to F.J.B.

Acknowledgments: Thanks are due to Jon Lindstrom, University of Pennsylvania, for providing samples of anti- $\alpha 7$ nAChR monoclonal antibodies mAb-306 and mAb-307 and to T. Kobayashi and S.B. Sato for a gift of fPEG-Chol.

Conflicts of Interest: The authors declare no conflict of interest.

\section{References}

1. Barrantes, F.J. Cholesterol effects on nicotinic acetylcholine receptor. J. Neurochem. 2007, 103, 72-80. [CrossRef]

2. Karlin, A. Emerging structure of the Nicotinic Acetylcholine receptors. Nat. Rev. Neurosci. 2002, 3, $102-114$. [CrossRef] [PubMed]

3. Whiting, P.; Lindstrom, J. Characterization of bovine and human neuronal nicotinic acetylcholine receptors using monoclonal antibodies. J. Neurosci. 1988, 8, 3395-3404. [CrossRef] [PubMed]

4. Jones, C. $\alpha 7$ Nicotinic Acetylcholine Receptor: A Potential Target in Treating Cognitive Decline in Schizophrenia. J. Clin. Psychopharmacol. 2018, 38, 247-249. [CrossRef] [PubMed]

5. Terry, A.V.; Callahan, P.M. Nicotinic Acetylcholine Receptor Ligands, Cognitive Function, and Preclinical Approaches to Drug Discovery. Nicotine Tob. Res. 2019, 21, 383-394. [CrossRef] [PubMed]

6. Ma, K.-G.; Qian, Y.-H. Alpha 7 nicotinic acetylcholine receptor and its effects on Alzheimer's disease. Neuropeptides 2019, 73, 96-106. [CrossRef] [PubMed]

7. Lombardo, S.; Maskos, U. Role of the nicotinic acetylcholine receptor in Alzheimer's disease pathology and treatment. Neuropharmacology 2015, 96, 255-262. [CrossRef] 
8. Russo, P.; Del Bufalo, A.; Frustaci, A.; Fini, M.; Cesario, A. Beyond acetylcholinesterase inhibitors for treating Alzheimer's disease: $\alpha 7-\mathrm{nAChR}$ agonists in human clinical trials. Curr. Pharm. Des. 2014, 20, 6014-6021. [CrossRef] [PubMed]

9. Hassan, M.; Shahzadi, S.; Raza, H.; Abbasi, M.A.; Alashwal, H.; Zaki, N.; Moustafa, A.A.; Seo, S.-Y. Computational investigation of mechanistic insights of $A \beta 42$ interactions against extracellular domain of $\mathrm{nAChR} \alpha 7$ in Alzheimer's disease. Int. J. Neurosci. 2019, 129, 666-680. [CrossRef]

10. Nagele, R.G.; D'Andrea, M.R.; Anderson, W.J.; Wang, H.-Y. Intracellular accumulation of beta-amyloid(1-42) in neurons is facilitated by the alpha 7 nicotinic acetylcholine receptor in Alzheimer's disease. Neuroscience 2002, 110, 199-211. [CrossRef]

11. Dineley, K.T. Beta-amyloid peptide-nicotinic acetylcholine receptor interaction: The two faces of health and disease. Front. Biosci. 2007, 12, 5030-5038. [CrossRef] [PubMed]

12. Shen, J.; Wu, J. Nicotinic Cholinergic Mechanisms in Alzheimer's Disease. Int. Rev. Neurobiol. 2015, 124, 275-292. [CrossRef]

13. Kamerbeek, C.B.; Borroni, V.; Pediconi, M.F.; Sato, S.B.; Kobayashi, T.; Barrantes, F.J. Antibody-induced acetylcholine receptor clusters inhabit liquid-ordered and liquid-disordered domains. Biophys. J. 2013, 105, 1601-1611. [CrossRef]

14. Borroni, V.; Barrantes, F.J. Cholesterol modulates the rate and mechanism of acetylcholine receptor internalization. J. Biol. Chem. 2011, 286, 17122-17132. [CrossRef] [PubMed]

15. Borroni, V.; Borroni, V.; Baier, C.J.; Lang, T.; Bonini, I.; White, M.M.; Garbus, I.; Barrantes, F.J. Cholesterol depletion activates rapid internalization of submicron-sized acetylcholine receptor domains at the cell membrane. Mol. Membr. Biol. 2007, 24, 1-15. [CrossRef]

16. Kumari, S.; Borroni, V.; Chaudhry, A.; Chanda, B.; Massol, R.; Mayor, S.; Barrantes, F.J. Nicotinic acetylcholine receptor is internalized via a Rac-dependent, dynamin-independent endocytic pathway. J. Cell Biol. 2008, 181, 1179-1193. [CrossRef]

17. Pato, C.; Stetzkowski-Marden, F.; Gaus, K.; Recouvreur, M.; Cartaud, A.; Cartaud, J. Role of lipid rafts in agrin-elicited acetylcholine receptor clustering. Chem. -Biol. Interact. 2008, 175, 64-67. [CrossRef]

18. Stetzkowski-Marden, F.; Gaus, K.; Recouvreur, M.; Cartaud, A.; Cartaud, J. Agrin elicits membrane lipid condensation at sites of acetylcholine receptor clusters in C2C12 myotubes. J. Lipid Res. 2006, 47, 2121-2133. [CrossRef]

19. Pediconi, M.F.; Gallegos, C.E.; De Los Santos, E.B.; Barrantes, F.J. Metabolic cholesterol depletion hinders cell-surface trafficking of the nicotinic acetylcholine receptor. Neuroscience 2004, 128, 239-249. [CrossRef] [PubMed]

20. Chen, T.; Wang, Y.; Zhang, T.; Zhang, B.; Chen, L.; Zhao, L.; Chen, L. Simvastatin Enhances Activity and Trafficking of $\alpha 7$ Nicotinic Acetylcholine Receptor in Hippocampal Neurons Through PKC and CaMKII Signaling Pathways. Front. Pharm. 2018, 9. [CrossRef]

21. Báez-Pagán, C.A.; del Hoyo-Rivera, N.; Quesada, O.; Otero-Cruz, J.D.; Lasalde-Dominicci, J.A. Heterogeneous Inhibition in Macroscopic Current Responses of Four Nicotinic Acetylcholine Receptor Subtypes by Cholesterol Enrichment. J. Membr Biol. 2016, 249, 539-549. [CrossRef] [PubMed]

22. Barthold, D.; Joyce, G.; Brinton, R.D.; Wharton, W.; Kehoe, P.G.; Zissimopoulos, J. Association of combination statin and antihypertensive therapy with reduced Alzheimer's disease and related dementia risk. PLoS ONE 2020, 15, e0229541. [CrossRef] [PubMed]

23. Barrantes, F.J.; Borroni, V.; Vallés, S. Neuronal nicotinic acetylcholine receptor-cholesterol crosstalk in Alzheimer's disease. Febs Lett. 2010, 584, 1856-1863. [CrossRef] [PubMed]

24. Xuan, K.; Zhao, T.; Qu, G.; Liu, H.; Chen, X.; Sun, Y. The efficacy of statins in the treatment of Alzheimer's disease: A meta-analysis of randomized controlled trial. Neurol. Sci. 2020, 41, 1391-1404. [CrossRef]

25. Jick, H.; Zornberg, G.L.; Jick, S.S.; Seshadri, S.; Drachman, D.A. Statins and the risk of dementia. Lancet 2000, 356, 1627-1631. [CrossRef]

26. Wolozin, B. Cholesterol, statins and dementia. Curr. Opin. Lipidol. 2004, 15, 667-672. [CrossRef]

27. Johnson-Anuna, L.N.; Eckert, G.P.; Keller, J.H.; Igbavboa, U.; Franke, C.; Fechner, T.; Schubert-Zsilavecz, M.; Karas, M.; Müller, W.E.; Wood, W.G. Chronic administration of statins alters multiple gene expression patterns in mouse cerebral cortex. J. Pharmacol. Exp. Ther. 2005, 312, 786-793. [CrossRef]

28. Sodero, A.O.; Barrantes, F.J. Pleiotropic effects of statins on brain cells. Biochim. Biophys. Acta Biophys. Incl. Photosynth. 2020, 1862, 183340. [CrossRef] 
29. Samuel, N.; Wonnacott, S.; Lindstrom, J.; Futerman, A.H. Parallel increases in [ $\alpha-125 \mathrm{I}]$ bungarotoxin binding and $\alpha 7$ nicotinic subunit immunoreactivity during the development of rat hippocampal neurons in culture. Neurosci. Lett. 1997, 222, 179-182. [CrossRef]

30. Kaech, S.; Banker, G. Culturing hippocampal neurons. Nat. Protoc. 2006, 1, 2406-2415. [CrossRef]

31. Genaro-Mattos, T.C.; Anderson, A.; Allen, L.B.; Korade, Z.; Mirnics, K. Cholesterol Biosynthesis and Uptake in Developing Neurons. ACS Chem. Neurosci. 2019, 10, 3671-3681. [CrossRef] [PubMed]

32. Kirsch, C.; Eckert, G.P.; Mueller, W.E. Statin effects on cholesterol micro-domains in brain plasma membranes. Biochem. Pharmacol. 2003, 65, 843-856. [CrossRef]

33. Eckert, G.P.; Kirsch, C.; Mueller, W.E. Differential effects of lovastatin treatment on brain cholesterol levels in normal and apoE-deficient mice. Neuroreport 2001, 12, 883-887. [CrossRef]

34. Sebastião, A.M.; Colino-Oliveira, M.; Assaife-Lopes, N.; Dias, R.B.; Ribeiro, J.A. Lipid rafts, synaptic transmission and plasticity: Impact in age-related neurodegenerative diseases. Neuropharmacology 2013, 64, 97-107. [CrossRef] [PubMed]

35. Dason, J.S.; Smith, A.J.; Marin, L.; Charlton, M.P. Vesicular sterols are essential for synaptic vesicle cycling. J. Neurosci. 2010, 30, 15856-15865. [CrossRef]

36. Renner, M.; Choquet, D.; Triller, A. Control of the postsynaptic membrane viscosity. J. Neurosci. 2009, 29, 2926-2937. [CrossRef]

37. Brachet, A.; Norwood, S.; Brouwers, J.F.; Palomer, E.; Helms, J.B.; Dotti, C.G.; Esteban, J.A. LTP-triggered cholesterol redistribution activates Cdc42 and drives AMPA receptor synaptic delivery. J. Cell Biol. 2015, 208, 791-806. [CrossRef]

38. Korinek, M.; Gonzalez-Gonzalez, I.M.; Smejkalova, T.; Hajdukovic, D.; Skrenkova, K.; Krusek, J.; Horak, M.; Vyklicky, L. Cholesterol modulates presynaptic and postsynaptic properties of excitatory synaptic transmission. Sci. Rep. 2020, 10, 12651. [CrossRef]

39. Martín-Segura, A.; Ahmed, T.; Casadomé-Perales, Á.; Palomares-Perez, I.; Palomer, E.; Kerstens, A.; Munck, S.; Balschun, D.; Dotti, C.G. Age-associated cholesterol reduction triggers brain insulin resistance by facilitating ligand-independent receptor activation and pathway desensitization. Aging Cell 2019, 18, e12932. [CrossRef]

40. Sodero, A.O.; Weissmann, C.; Ledesma, M.D.; Dotti, C.G. Cellular stress from excitatory neurotransmission contributes to cholesterol loss in hippocampal neurons aging in vitro. Neurobiol. Aging 2011, 32, 1043-1053. [CrossRef]

41. Thorvaldsson, V.; Skoog, I.; Johansson, B. Cholesterol and cognitive aging: Between-person and within-person associations in a population-based representative sample not on lipid-lowering medication. Psychol. Aging 2020, 35, 508-516. [CrossRef] [PubMed]

42. Martin, M.G.; Ahmed, T.; Korovaichuk, A.; Venero, C.; Menchón, S.A.; Salas, I.; Munck, S.; Herreras, O.; Balschun, D.; Dotti, C.G. Constitutive hippocampal cholesterol loss underlies poor cognition in old rodents. EMBO Mol. Med. 2014, 6, 902-917. [CrossRef] [PubMed]

43. Egawa, J.; Pearn, M.L.; Lemkuil, B.P.; Patel, P.M.; Head, B.P. Membrane lipid rafts and neurobiology: Age-related changes in membrane lipids and loss of neuronal function. J. Physiol. 2016, 594, 4565-4579. [CrossRef]

44. Gamba, P.; Staurenghi, E.; Testa, G.; Giannelli, S.; Sottero, B.; Leonarduzzi, G. A Crosstalk Between Brain Cholesterol Oxidation and Glucose Metabolism in Alzheimer's Disease. Front. Neurosci. 2019, 13, 556. [CrossRef]

45. Tang, Q.; Wang, F.; Yang, J.; Peng, H.; Li, Y.; Li, B.; Wang, S. Revealing a Novel Landscape of the Association Between Blood Lipid Levels and Alzheimer's Disease: A Meta-Analysis of a Case-Control Study. Front. Aging Neurosci. 2019, 11, 370. [CrossRef]

46. Jin, U.; Park, S.J.; Park, S.M. Cholesterol Metabolism in the Brain and Its Association with Parkinson's Disease. Exp. Neurobiol. 2019, 28, 554-567. [CrossRef]

47. González-Guevara, E.; Cárdenas, G.; Pérez-Severiano, F.; Martínez-Lazcano, J.C. Dysregulated Brain Cholesterol Metabolism Is Linked to Neuroinflammation in Huntington's Disease. Mov. Disord. 2020, 35, 1113-1127. [CrossRef] [PubMed]

48. Ibrahim, M.M.; Gabr, M.T. Multitarget therapeutic strategies for Alzheimer's disease. Neural Regen. Res. 2019, 14, 437-440. [CrossRef] [PubMed] 
49. Hampel, H.; Mesulam, M.-M.; Cuello, A.C.; Farlow, M.R.; Giacobini, E.; Grossberg, G.T.; Khachaturian, A.S.; Vergallo, A.; Cavedo, E.; Snyder, P.J.; et al. The cholinergic system in the pathophysiology and treatment of Alzheimer's disease. Brain 2018, 141, 1917-1933. [CrossRef] [PubMed]

50. Roensch, J.; Crisby, M.; Nordberg, A.; Xiao, Y.; Zhang, L.-J.; Guan, Z.-Z. Effects of statins on $\alpha 7$ nicotinic receptor, cholinesterase and $\alpha$-form of secreted amyloid precursor peptide in SH-SY5Y cells. Neurochem. Int. 2007, 50, 800-806. [CrossRef]

51. Chen, T.; Wang, C.; Sha, S.; Zhou, L.; Chen, L.; Chen, L. Simvastatin Enhances Spatial Memory and Long-Term Potentiation in Hippocampal CA1 via Upregulation of $\alpha 7$ Nicotinic Acetylcholine Receptor. Mol. Neurobiol. 2016, 53, 4060-4072. [CrossRef] [PubMed]

52. Kwak, B.; Mulhaupt, F.; Myit, S.; Mach, F. Statins as a newly recognized type of immunomodulator. Nat. Med. 2000, 6, 1399-1402. [CrossRef] [PubMed]

53. Taqueti, V.R.; Ridker, P.M. Lipid-Lowering and Anti-Inflammatory Benefits of Statin Therapy: More Than Meets the Plaque. Circ. Cardiovasc Imaging 2017, 10, e006676. [CrossRef]

54. Mohammadkhani, N.; Gharbi, S.; Rajani, H.F.; Farzaneh, A.; Mahjoob, G.; Hoseinsalari, A.; Korsching, E. Statins: Complex outcomes but increasingly helpful treatment options for patients. Eur. J. Pharm. 2019, 863, 172704. [CrossRef]

55. Scorticati, C.; Formoso, K.; Frasch, A.C. Neuronal glycoprotein M6a induces filopodia formation via association with cholesterol-rich lipid rafts. J. Neurochem. 2011, 119, 521-531. [CrossRef]

Publisher's Note: MDPI stays neutral with regard to jurisdictional claims in published maps and institutional affiliations. 